\title{
Tumor necrosis factor-alpha-induced reduction of glomerular filtration rate in rats with fulminant hepatic failure
}

\author{
Jing-Bo Wang ${ }^{1,2,6}$, Dong-Lei Wang ${ }^{1,6}$, Hai-Tao Wang ${ }^{3}$, Zhao-Han Wang ${ }^{1}$, Ying Wen ${ }^{1}$, Cui-Ming Sun ${ }^{1}$, \\ Yi-Tong Zhao ${ }^{2}$, Jian $\mathrm{Wu}^{4,5}$ and Pei Liu $^{1}$
}

The mechanism of renal failure during fulminant hepatic failure (FHF) or end-stage of liver disease is not fully understood. The present study aims to delineate the mechanisms of decreased glomerular filtration rate (GFR) in acute hepatic failure. A rat model of renal insufficiency in severe liver injury was established by lipopolysaccharide (LPS) plus D-galactosamine (GalN) exposure. GFR was evaluated by continuous infusion of fluorescein isothiocyanate-inulin with implanted micro-osmotic pumps. GalN/LPS intoxication resulted in severe hepatocyte toxicity as evidenced by liver histology and biochemical tests, whereas renal morphology remained normal. GFR was reduced by 33\% of the controls $12 \mathrm{~h}$ after GalN/LPS exposure, accompanied with a decreased serum sodium levels, a marked increase in serum TNF- $\alpha$ and ET-1 levels as well as significantly upregulated renal type 1 inositol 1,4,5-trisphosphate receptor $\left(\mathrm{IP}_{3} \mathrm{R} 1\right)$ expression. The upregulated $\mathrm{IP}_{3} \mathrm{R} 1$ expression was abrogated by the treatment of anti-TNF- $\alpha$ antibodies, but not by 2 -aminoethoxydiphenylborate (2-APB), which blocks the inositol 1,4,5-trisphosphate signaling pathway. Treatments with either TNF- $\alpha$ antibodies or 2-APB also significantly improved the compromised GFR, elevated serum urea nitrogen and creatinine levels, and reversed the decrease in glomerular inulin space and the increase in glomerular calcium content in GalN/LPS-exposed rats. The extent of acute liver injury as reflected by serum ALT levels was much more attenuated by anti-TNF- $\alpha$ antibodies than by 2-APB. Liver histology further confirmed that anti-TNF- $\alpha$ antibodies conferred better protection than 2-APB in GaIN/LPS-exposed rats. LPS-elicited TNF- $\alpha$ over-production is responsible for decreased GFR through $I P_{3} R 1$ overexpression, and the compromised GFR resulted in the development of acute renal failure in rats with FHF.

Laboratory Investigation (2014) 94, 740-751; doi:10.1038/labinvest.2014.71; published online 2 June 2014

KEYWORDS: acute renal failure; fulminant hepatic failure; glomerular calcium content; glomerular filtration rate; tumor necrosis factor-alpha; type 1 inositol 1,4,5-trisphosphate receptor

\section{INTRODUCTION}

Acute renal failure may occur during fulminant liver failure with an increased mortality rate. Reduction in the effective circulating blood volume and subsequent hypoperfusion of the kidneys may be the possible pathogenesis of renal failure in patients with severe liver failure. ${ }^{1}$ It is accompanied by renal vasoconstriction, which leads to a pronounced reduction in glomerular filtration rate (GFR). ${ }^{2,3}$ The afferent arteriole has an important role in the regulation of renal blood flow and GFR, thus contributing to the control of extracellular fluid volume and arterial pressure. Vascular smooth muscle cells (VSMC) in the preglomerular resistance vessels (interlobular artery and afferent arteriole) mediate constriction or dilation of the vessels, ie, changes in luminal diameter, in turn regulating renal vascular resistance, renal blood flow, and GFR. ${ }^{4}$ High levels of plasma angiotensin II,

\footnotetext{
${ }^{1}$ Department of Infectious Diseases, The First Affiliated Hospital, China Medical University, Shenyang City, People's Republic of China; ${ }^{2}$ Division of Gastroenterology, Department of Internal Medicine, The Sixth People's Hospital of Shenyang, Shenyang City, People's Republic of China; ${ }^{3}$ Division of Hepatobiliary Diseases, Department of Surgery, The Affiliated Shenzhou Hospital of Shenyang Medical College, Shenyang City, People's Republic of China; ${ }^{4}$ Department of Internal Medicine, Division of Gastroenterology and Hepatology, University of California, Davis Medical Center, Sacramento, CA, USA and ${ }^{5}$ Key Laboratory of Molecular Virology, Fudan University College of Basic Medical Sciences, Shanghai, People's Republic of China

Correspondence: Professor P Liu, MD, PhD, Department of Infectious Diseases, The First Affiliated Hospital, China Medical University, 155 Nanjing North Street,

Shenyang 110001, People's Republic of China or Professor J Wu, MD, PhD, UC Davis Medical Center, Institute of Regenerative Cures, 2921 Stockton Boulevard, Suite 1610, Sacramento, CA 95817, USA.

E-mail: syliupei2013@163.com.cn or jdwu@ucdavis.edu

${ }^{6}$ These two authors contribute to this work equally.

Received 25 November 2013; revised 11 April 2014; accepted 20 April 2014
} 
endothelin-1 (ET-1), norepinephrine (NE), and TNF- $\alpha$ in patients with liver failure, which may induce an increase in intracellular $\mathrm{Ca}^{2+}$ concentration $\left(\left[\mathrm{Ca}^{2+}\right] \mathrm{i}\right)$ in preglomerular VSMCs (PVSMCs) by stimulating calcium mobilization from intracellular stores and calcium entry from the extracellular fluid. ${ }^{5,6}$ Multifactorial mechanisms were involved in disordered regulation of renal blood flow and GFR. ${ }^{7}$ As the control of renal vasoconstriction in renal failure is multifactorial, strategies in inhibiting vaso-constrictive activity did not achieve the desired efficacy. ${ }^{8,9}$ A growing body of evidence suggests that serum level of tumor necrosis factor $\alpha(\mathrm{TNF}-\alpha)$ increases significantly in patients with severe liver injury, ${ }^{10,11}$ whereas TNF- $\alpha$ inhibitor such as oxpentifylline reduced the incidence of renal failure rate from $35 \%$ to $8 \%$ and hospital mortality from $46 \%$ to $24 \% .^{12}$ Therefore, it is conceivable that TNF- $\alpha$ has a crucial role in the development of renal failure during hepatic insufficiency. ${ }^{6}$

Recently, we found that TNF- $\alpha$ increased the expression of inositol 1,4,5-trisphosphate receptors $\left(\mathrm{IP}_{3} \mathrm{R}\right)$, mediating through the TNF receptor 1/phosphatidyl-phospholipase C/protein kinase $\mathrm{C} \alpha$ (TNFR1/PC-PLC/PKC $\alpha$ ) and TNFR2 signaling pathways in human mesangial cells (HMC). ${ }^{13}$ The aim of the present study is to further delineate the role of TNF- $\alpha$ in the development of the renal failure in fulminant hepatic failure (FHF). Our hypothesis is that TNF- $\alpha$ increases inositol 1,4,5-trisphosphate $\left(\mathrm{IP}_{3}\right)$-induced $\mathrm{Ca}^{2+}$ release in response to a variety of vasoconstrictors by inducing $\mathrm{IP}_{3} \mathrm{R} 1$ overexpression, causing glomerular mesangial cells (GMC) and renal VSMCs to contract, and in turn lead to a decrease in GFR and the development of acute renal failure. To test the hypothesis, we established an animal model of FHF in which severe renal failure is confirmed by reduction of GFR and changes in blood urea nitrogen (BUN), creatinine and sodium ion levels without histologic alterations in light microscope and electronic microscope (EM). With this rat model, we investigated the effects of TNF- $\alpha$ on GFR in order to understand the mechanisms of TNF- $\alpha$ in modulating the pathogenesis of acute renal failure.

\section{MATERIALS AND METHODS \\ Animals}

Male Sprague-Dawley rats weighing $\sim 220$ g were purchased from Laboratory Animal Center in China Medical University, China. They were housed under a controlled condition of temperature $\left(23 \pm 3{ }^{\circ} \mathrm{C}\right)$ and relative humidity $(50 \pm 20 \%)$, with light illumination for $12 \mathrm{~h}$ a day. They were allowed access to food and tap water throughout the acclimatization and experimental periods. All procedures were approved by the Institutional Review Board according to the Animal Protection Act of China.

\section{Chemicals and Reagents}

D-Galactosamine hydrochloride (GalN), lipopolysaccharide (LPS), TNF- $\alpha$ monoclonal antibody and 2-aminoethoxy- diphenylborate (2-APB) were obtained from Sigma Chemical (St Louis, MO, USA). Micro-osmotic pumps at a release rate of $1.0 \mu \mathrm{l} / \mathrm{h}$ were purchased from Durect (Cupertino, CA, USA). Primary polyclonal antibody against rat $\mathrm{IP}_{3} \mathrm{R} 1$ was the product of Synaptic Systems (Goettingen, Germany). Realtime PCR kit was obtained from Takaka (Dalian, China).

\section{Rat Model of FHF}

FHF was induced in rats as reported previously. ${ }^{14,15}$ A mixture of GalN $(400 \mathrm{mg} / \mathrm{kg})$ and LPS $(32 \mu \mathrm{g} / \mathrm{kg})$ in saline was administrated via the tail vein at a volume of $2 \mathrm{ml} / \mathrm{kg}$ under anesthesia. The initial study comprised four groups (10-20 rats per group): (1) experiment group, treated with GalN and LPS (GalN/LPS); (2) normal saline (NS) treatment group; (3) GalN treatment group; (4) LPS treatment group. Systolic blood pressure (SBP) was detected $12 \mathrm{~h}$ after injection using rat tail blood pressure system (IITC Life Science, Woodland Hills, CA, USA).

Five $\mathrm{ml}$ of blood was collected from the saphenous vein into a heparinized capillary tube using a sterile 23-gauge syringe needle. ${ }^{16}$ Serum biochemical markers and cytokine levels were determined using commercial kits. Rats were killed under anesthesia 3, 6, 9, 12 and $24 \mathrm{~h}$ after GalN/LPS injection. Liver and kidney tissues were collected and fixed for histological analysis. Unfixed specimens were frozen till further analysis.

\section{Preparation of Fluorescein Isothiocyanate (FITC)-Inulin Solution}

FITC-inulin (24\%) was dissolved in $0.9 \% \mathrm{NaCl}$ solution as described. ${ }^{17}$ To remove residual FITC unbounded to inulin, the solution was dialyzed in $1000 \mathrm{ml}$ of $0.9 \% \mathrm{NaCl}$ at room temperature for $24 \mathrm{~h}$ using a $1000-\mathrm{Da}$ cutoff dialysis membrane (Spectrum Laboratories, Rancho Dominguez, CA, USA) in dark and then sterilized by filtration through a $0.22-\mu \mathrm{m}$ filter.

\section{Implantation of Micro-osmotic Pumps}

Thirty-five rats were anesthetized with an intraperitoneal injection of pentobarbital sodium $(40 \mathrm{mg} / \mathrm{kg})$. Two microosmotic pumps filled with $\sim 100 \mu \mathrm{l}$ of $8 \%$ FITC-inulin were inserted into the peritoneal cavity. A pilot study revealed that plasma FITC levels were inadequate to measure GFR when a single micro-osmotic pump was implanted. After two pumps were implanted in the same animal, a 2-6-fold increase in plasma fluorescent levels was detected.

\section{Animal Groups and Treatment}

Rats with an implementation of two micro-osmotic pumps were randomly divided into six groups: (1) NS control; (2) GalN; (3) LPS; (4) GalN/LPS; (5) GalN/LPS + anti-TNF- $\alpha$ and (6) GalN/LPS + 2-APB. Antibodies against TNF- $\alpha$ ( $5 \mathrm{mg} /$ $\mathrm{kg})^{18,19}$ or 2 -APB $(2 \mathrm{mg} / \mathrm{kg})^{20}$ were administered $30 \mathrm{~min}$ before GalN/LPS treatment. Blood was sampled through the saphenous vein after the treatments. Serum was obtained 
for the measurement of FITC fluorescent intensity and biochemical assays. Liver and renal specimens were fixed for histopathologic examination. Frozen specimens were used for quantitative analysis of $\mathrm{IP}_{3} \mathrm{R} 1$ by western blot and real-time RT-PCR.

\section{Measurement of FITC-Inulin in Plasma}

It was reported that $\mathrm{pH}$ value significantly affects FITC fluorescence intensity, ${ }^{21}$ therefore all plasma samples were buffered to pH 7.4 with $500 \mathrm{mM}$ 4-(2-hydroxyethyl)-1piperazineethanesulfonic acid (HEPES). Fluorescent intensity was determined using a fluoroscan spectrophotometer (F-4500, HITACHI, Japan) with excitation at $485 \mathrm{~nm}$ and emission at $538 \mathrm{~nm}$.

The linear correlation between fluorescent intensity and inulin concentration was established by measuring fluorescent intensity in serial dilutions of an FITC-inulin solution of known concentration. A standard curve for blood samples was generated using FITC-inulin concentrations of $0-300 \mu \mathrm{g} / \mathrm{ml} .{ }^{17}$ A regression coefficient of 0.99 was achieved between fluorescent readings and plasma FITC-inulin concentration, confirming the reliability of fluorescent spectrometry to measure FITC-inulin.

\section{Calculation of GFR}

GFR was evaluated 7 days after the implantation of microosmotic pumps based on the equation of inulin clearance (inulin clearance $=$ inulin infusion rate/steady-state blood inulin concentration), as previously described. ${ }^{17,22} \mathrm{GFR}_{1}$ was expressed in microliters per minute $(\mathrm{ml} / \mathrm{min})$, and $\mathrm{GFR}_{2}$ was expressed in microliters per minute per kilogram body weight $(\mathrm{ml} / \mathrm{min} / \mathrm{kg} \mathrm{BW})$, as well as $\mathrm{GFR}_{3}$, which was expressed in microliters per minute per gram kidney weight $(\mathrm{ml} / \mathrm{min} / \mathrm{g} \mathrm{KW})$. Obviously, GFR2 and GFR3 reflect GFR more precisely than GFR1 due to a correction with body weight or kidney weight.

\section{Western Blot Analysis of $\mathbf{I P}_{\mathbf{3}} \mathbf{R} \mathbf{1}$}

Total renal protein was extracted in lysis buffer $(50 \mathrm{mM}$ Tris- $\mathrm{HCl}, \mathrm{pH} 7.4$, containing $150 \mathrm{mM} \mathrm{NaCl}, 1 \%$ Triton-100, $1 \%$ sodium deoxycholate, $0.1 \%$ SDS, $1 \mathrm{mM}$ EDTA, $5 \mathrm{mg} / \mathrm{ml}$ leupeption, sodium orthovanadate, sodium fluoride, $1 \mathrm{mM}$ PMSF, and centrifuged $(12000 \mathrm{~g}, 12 \mathrm{~min})$. Protein concentration was determined by BCA protein assay and equal amounts of protein were run in $8 \%$ SDS-PAGE gel, and transferred to PVDF membrane. The PVDF membrane was then blocked with $5 \%$ nonfat dry milk for $2 \mathrm{~h}$. After being blocked, PVDF membrane was immunoblotted with the primary antibody (polyclonal $\mathrm{IP}_{3} \mathrm{R} 1$ antibody) overnight. The membrane was washed three times with Tris- $\mathrm{HCl}-\mathrm{NaCl}-$ Tween 20 solution (TBST) to remove unbound primary antibody. Then, the membrane was incubated with horseradish peroxidase (HRP)-conjugated goat-anti-rabbit IgG for $2 \mathrm{~h}$, washed three times with TBST to remove unbound secondary antibody, and incubated with BCIP/NBT (5-bromo-4-chloro-3-indolyl phosphate/nitro blue tetrazolium) liquid substrate reagent for $5 \mathrm{~min}$. The reaction was stopped by $\mathrm{H}_{2} \mathrm{O}$. $\beta$-actin was used for an internal loading control. A densitometer (model GS-700, Bio-Rad Laboratories) was used to quantify $230-\mathrm{kDa}$ bands of $\mathrm{IP}_{3} \mathrm{R} 1$ and $45-\mathrm{kDa}$ bands of $\beta$-actin. Relative protein levels were calculated based on densitometric count ratio of $\mathrm{IP}_{3} \mathrm{R} 1$ over $\beta$-actin bands. ${ }^{23}$

\section{Real-Time RT-PCR Analysis of IP $\mathbf{3} \mathbf{R} \mathbf{1}$ mRNA Levels}

Total RNA was extracted using TRIzol following the manufacturer's protocol. RNA concentration was determined by UV analysis and diluted to $500 \mathrm{ng} / \mu \mathrm{l}$ with DEPC water. RNA was incubated at $37^{\circ} \mathrm{C}$ for $15 \mathrm{~min}$ followed by $85^{\circ} \mathrm{C}$ for $5 \mathrm{~s}$ for reverse transcription (RT) for cDNA generation. The cDNA underwent 45 cycles of PCR $\left(95^{\circ} \mathrm{C}\right.$ for $30 \mathrm{~s}, 95^{\circ} \mathrm{C}$ for $5 \mathrm{~s}$, and $57^{\circ} \mathrm{C}$ for $20 \mathrm{~s}$, and $72^{\circ} \mathrm{C}$ for $30 \mathrm{~s}$ ) in Rotor-Gene 6000 PCR machine (Corbett Life Science, Sydney, Australia). The sense and antisense primers of rat $\mathrm{IP}_{3} \mathrm{R} 1$ were $5^{\prime}$-TCTGGC CAGCTGTCAGAACTAAAG- $3^{\prime}$ and $5^{\prime}$-GTGGGTTGACATTC ATGTGAGGA- $3^{\prime}$, respectively. The sense and antisense primers of rat glyceraldehyde 3-phosphate dehydrogenase $\left(\right.$ GAPDH) were $5^{\prime}$-GACAACTTTGGCATCGTGGA- $3^{\prime}$ and $5^{\prime}$-GACAACTTTGGCATCGTGGA-3'. Relative level of $\mathrm{IP}_{3} \mathrm{R} 1$ gene expression was calculated based on amplification of a standard curve after the series of dilution of cDNA. GAPDH was used for a house-keeping gene control. ${ }^{24}$

\section{Isolation of Rat Glomeruli}

Animals were decapitated under ether anesthesia and kidneys were collected. The glomeruli were isolated by a gradual sieving technique. Briefly, renal capsule was removed and the cortex was minced with a razor blade to a paste-like consistency and strained through a $250-\mu \mathrm{m}$ steel sieve. Then, the suspension was further filtered through two consecutive steel sieves $(120$ and $70 \mu \mathrm{m})$. The glomeruli retained on the top of $70 \mu \mathrm{m}$ sieve were washed and resuspended in ice-cold PBS. Tubular contamination was less than $5 \%$ as assessed under the light microscope. The entire procedure was carried out in an ice bath within $1 \mathrm{~h} .^{23,24}$

\section{Determination of Glomerular Inulin Space}

About 4000 glomeruli were resuspended in $400 \mu \mathrm{l}$ ice-cold $\mathrm{Ca}^{2+}$-free buffer (containing $1 \%$ bovine serum albumin). They were incubated with FITC-inulin $(100 \mu \mathrm{g}$, Sigma $)$ at $37^{\circ} \mathrm{C}$ in shaking water bath for $30 \mathrm{~min}$, then equally divided into two tubes. One portion of glomeruli was treated with ET-1 (100 nM, Sigma) for $10 \mathrm{~min}$, another portion was used as a control group. After the treatment, glomeruli were centrifuged at $5000 \mathrm{~g}$ for $5 \mathrm{~s}$. Twenty $\mu \mathrm{l}$ supernatant and whole glomerular pellet were separately suspended overnight in $500 \mu \mathrm{l}$ of $0.3 \%$ Triton X-100 solution. Fluorescence intensity (FI) of glomeruli was measured by a spectrofluorometer. Glomerular inulin space (GIS) of single 
glomerulus was calculated as follows: $:^{23,24}$

$$
\begin{aligned}
& \text { GIS }(\mathrm{nl} / \text { glomerulus })= \\
& \quad \frac{\mathrm{FI}-\text { pellet }(\mu \mathrm{g} / \mathrm{ml})}{\mathrm{FI}-\text { supernatant }(\mu \mathrm{g} / \mathrm{ml})} \times \frac{1}{\text { number of glomeruli in pellet }}
\end{aligned}
$$

\section{Measurements of Intracellular $\left[\mathrm{Ca}^{2+}\right] \mathrm{i}$ in Glomeruli}

Glomeruli were isolated according to the method described above. Two thousand glomeruli were resuspended in $200 \mu \mathrm{l}$ Hank's saline solution and incubated with Fura-2/AM $(10 \mu \mathrm{M})$ at $37^{\circ} \mathrm{C}$ in dark shaking water bath for $45 \mathrm{~min}$. Then, excess Fura-2 was washed away with D-Hank's saline solution, and allowed to de-esterify for $10 \mathrm{~min}$. Fluorescence excitation of Fura-2 was performed at $340 / 380 \mathrm{~nm}$, and emission was detected above $510 \mathrm{~nm}$. After the base line was recorded, the fluorescence ratio $(340 / 380 \mathrm{~nm})$ of each sample was recorded under the treatment with ET-1 (100 nM, Sigma), during a 0.1-s exposure at $20.0 \mathrm{~s}$ intervals for $10 \mathrm{~min}$. All experiments were carried out at $37^{\circ} \mathrm{C}$, $\mathrm{pH}$ 7.4. At the end of each experiment, $\mathrm{CaCl}_{2}\left(2.5 \times 10^{-3} \mathrm{M}\right)$ and EGTA $(5 \mathrm{mM})$ were respectively added in to obtain maximal fluorescent intensity $\left(F_{\max }\right)$ and minimal fluorescence $\left(F_{\min }\right)$. The calculating equation is as follows: ${ }^{25,26}$

$\left[\mathrm{Ca}^{2+}\right] \mathrm{i}(\mathrm{nmol} / \mathrm{l})=K_{\mathrm{d}} \times\left[\left(R-R_{\min }\right) /\left(R_{\max }-R\right)\right] \times\left(F_{0} / F_{\mathrm{s}}\right)$

Here $K_{\mathrm{d}}$ equals $224 \mathrm{nmol} / \mathrm{l}$.

\section{Histologic Analysis}

Liver and kidney specimens were fixed in buffered formalin and embedded in paraffin. Tissue sections were stained with hematoxylin and eosin (H-E) routinely, and examined in a microscope. Representative micrographic images were recorded with a digital camera at $\times 200$ or $\times 400$.

\section{EM Specimen Preparation and Examination}

The EM preparation of renal cortex specimens was performed as described previously ${ }^{27}$ and the sections were observed in JEOL JEM 1230 Transmission Electron Microscope.

\section{Serum Analysis}

Serum levels of alanine transaminase (ALT), BUN, creatinine $(\mathrm{Cr})$, potassium ion $\left(\mathrm{K}^{+}\right)$, sodium ion $\left(\mathrm{Na}^{+}\right)$, and chloride ion $\left(\mathrm{Cl}^{-}\right)$were analyzed with commercial kits. Serum levels of TNF- $\alpha$ and ET-1 were quantified by ELISA using commercial kits (R\&D Systems, Abingdon, UK).

\section{Statistical Analysis}

Software SPSS 13.0 was used in statistical analysis. Each parameter was expressed as mean \pm s.e.m., and compared using one-factor analysis of variance and least significant difference (LSD) for multiple comparisons among groups. $P<0.05$ was considered statistically significant.

\section{RESULTS}

Renal Failure Model Induced by GaIN/LPS Treatment

Intravenous administration of a high dose of GalN and LPS caused FHF in rats. Rat mortality reached 70\% (14/20) $24 \mathrm{~h}$ after the administration of GalN/LPS in rats. GalN/LPS treatment led to a marked increase in serum levels of ALT, BUN, Cr, K ${ }^{+}$, TNF- $\alpha$, and ET- 1 , whereas serum $\mathrm{Na}^{+}$and $\mathrm{Cl}^{-}$levels were decreased $12 \mathrm{~h}$ after the treatment (Table 1 ). Liver histology exhibited massive hemorrhage and hepatic necrosis as well as infiltration of inflammatory cells $12 \mathrm{~h}$ after GalN/LPS challenge (Figure 1a). In contrast, renal morphology of $\mathrm{H}-\mathrm{E}$ staining and ultrastructure examined by EM did not show any abnormalities in renal glomeruli and

\begin{tabular}{|c|c|c|c|c|c|c|c|c|}
\hline Group & ALT (IU/I) & BUN (mmol/l) & $\mathrm{Cr}(\mu \mathrm{mol} / \mathrm{l})$ & $\mathrm{K}^{+}(\mathrm{mmol} / \mathrm{l})$ & $\mathrm{Cl}^{-}(\mathrm{mmol} / \mathrm{l})$ & $\mathrm{Na}^{+}(\mathrm{mmol} / \mathrm{l})$ & TNF- $\alpha(p g / m l)$ & ET-1 $(\mathrm{pg} / \mathrm{ml})$ \\
\hline NS $(n=8)$ & $39.1 \pm 1.7$ & $5.7 \pm 0.4$ & $61.3 \pm 1.5$ & $5.2 \pm 0.1$ & $101.4 \pm 0.7$ & $141.3 \pm 0.3$ & $42.5 \pm 7.6$ & $17.8 \pm 1.4$ \\
\hline G/L6h $(n=5)$ & $508.2 \pm 209.7^{\mathrm{a}}$ & $9.9 \pm 0.4^{a, b}$ & $71.6 \pm 1.8^{\mathrm{a}, \mathrm{b}}$ & $5.9 \pm 0.3$ & $101.9 \pm 1.4^{\mathrm{a}}$ & $143.2 \pm 0.3^{\mathrm{a}}$ & $173.3 \pm 39.2$ & $29.1 \pm 5.6$ \\
\hline G/L9h $(n=6)$ & $1760.8 \pm 649.2^{\mathrm{a}, \mathrm{b}}$ & $10.2 \pm 0.9^{a, b}$ & $68.8 \pm 0.9^{a}$ & $5.8 \pm 0.2$ & $100.9 \pm 0.7^{\mathrm{a}}$ & $141.5 \pm 0.3^{\mathrm{a}}$ & $549.3 \pm 200.3$ & $48.5 \pm 14.2$ \\
\hline G/L24h $(n=5)$ & $3145.6 \pm 485.9^{b}$ & $9.4 \pm 0.3^{\mathrm{a}, \mathrm{b}}$ & $71.6 \pm 2.8^{\mathrm{a}, \mathrm{b}}$ & $6.0 \pm 0.4$ & $96.5 \pm 1.0^{b}$ & $135.9 \pm 1.3^{b}$ & $280.9 \pm 107.3$ & $27.6 \pm 6.4$ \\
\hline $\mathrm{G} 12 \mathrm{~h}(n=10)$ & $92.6 \pm 11.7^{\mathrm{a}}$ & $8.2 \pm 0.4^{\mathrm{a}, \mathrm{b}}$ & $60.4 \pm 1.1^{\mathrm{a}}$ & $5.4 \pm 0.2^{\mathrm{a}}$ & $100.8 \pm 0.7^{\mathrm{a}}$ & $140.7 \pm 0.3^{\mathrm{a}}$ & $57.4 \pm 10.3^{\mathrm{a}}$ & $19.2 \pm 3.3^{\mathrm{a}}$ \\
\hline L12h $(n=10)$ & $42.8 \pm 2.6^{a}$ & $11.1 \pm 0.4^{a, b}$ & $67.7 \pm 1.0^{\mathrm{a}, \mathrm{b}}$ & $5.7 \pm 0.1^{a, b}$ & $99.2 \pm 1.2^{a, b}$ & $141.1 \pm 0.5^{\mathrm{a}}$ & $33.2 \pm 3.5^{\mathrm{a}}$ & $22.0 \pm 2.4^{a}$ \\
\hline anti-TNF $\alpha-G / L 12 h \quad(n=5)$ & $653.2 \pm 124.9^{\mathrm{a}, \mathrm{b}}$ & $12.2 \pm 1.0^{\mathrm{a}}$ & $68.2 \pm 0.6^{a}$ & $5.4 \pm 0.1^{\mathrm{a}}$ & $100.6 \pm 0.7^{a, b}$ & $137.9 \pm 1.3^{\mathrm{a}}$ & $162.6 \pm 63.4^{\mathrm{a}}$ & $15.6 \pm 2.5^{\mathrm{b}}$ \\
\hline 2-APB-G/L12h $(n=5)$ & $2264.4 \pm 223.6^{\mathrm{a}, \mathrm{b}}$ & $10.7 \pm 0.5^{a}$ & $75.0 \pm 3.3^{a}$ & $5.4 \pm 0.1^{\mathrm{a}}$ & $98.1 \pm 0.8^{a}$ & $140.4 \pm 0.8^{\mathrm{a}}$ & $2065.1 \pm 290.9^{b}$ & $16.1 \pm 3.1^{b}$ \\
\hline
\end{tabular}

Table 1 Serum levels of ALT, BUN, $\mathrm{Cr}, \mathrm{K}^{+}, \mathrm{Cl}^{-}, \mathrm{Na}^{+}$and cytokines (means \pm s.e.m.)

${ }^{\text {a }} P<0.05$ compared with GalN/LPS group (12 h). G = GalN, L = LPS.

${ }^{\mathrm{b}} \mathrm{P}<0.05$ as compared with N.S. control group.

Anti-TNF- $\alpha$ antibodies $(5 \mathrm{mg} / \mathrm{kg}$ ) or 2-APB ( $2 \mathrm{mg} / \mathrm{kg}$ ) was administered $0.5 \mathrm{~h}$ before GalN/LPS treatment via tail vein. Serum samples were collected at indicated time points after the treatment. Data represent means \pm s.e.m. 

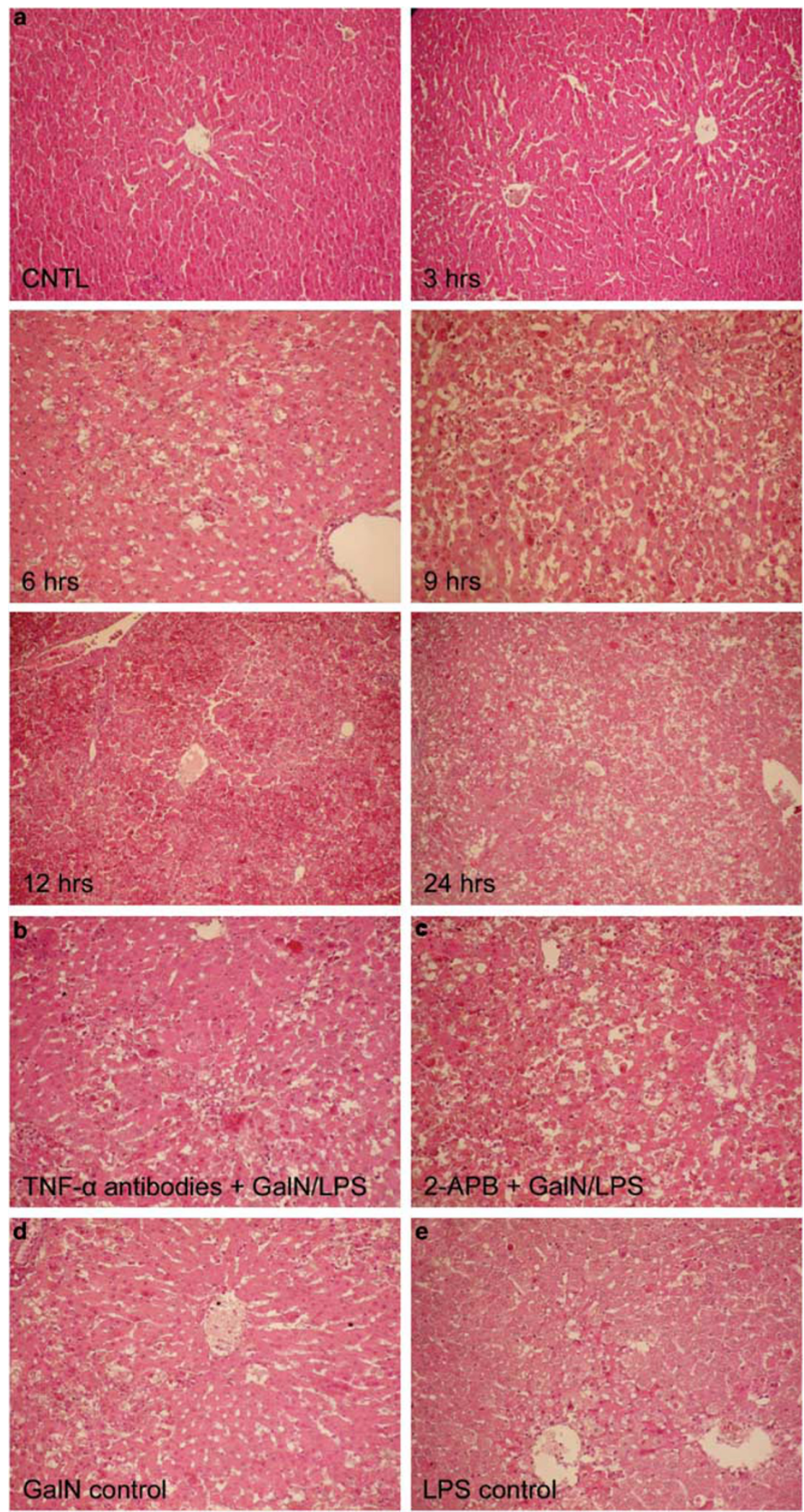

Figure 1 Representative micrographs of GalN/LPS-induced liver injury and effects of anti-TNF- $\alpha$ antibody. (a) Morphology of GalN/LPS-induced acute liver injury over time. The liver histology from rats $12 \mathrm{~h}$ after treatment with GaIN/LPS shows massive hemorrhage and necrosis. (b) Anti-TNF- $\alpha$ antibodies dramatically minimized liver injury, and the liver histology displays spotty or focal necrosis. (c) 2-APB slightly improved liver injury, and the liver histology shows or focal necrosis. (d,e) are GalN and LPS controls. H-E staining, magnification: $\times 200$. 
tubules during all time points (Figure 2 and Supplementary Figure 1). In the group of GalN/LPS treatment, five rats died $12 \mathrm{~h}$ after GalN/LPS injection. SBP between the group of GalN/LPS treatment $(n=10)$ and NS control group $(n=5)$ was not significantly different $(131.46 \pm 3.23$ vs $132.50 \pm$ $3.38 \mathrm{~mm} \mathrm{Hg}, P=0.861$ ). Either GalN or LPS alone caused mild liver injury histologically. Pretreatment with anti-TNF- $\alpha$ antibodies attenuated these pathological changes more effectively than 2-APB (spotty or focal necrosis $v s$ focal necrosis) (Figures $1 \mathrm{~b}$ and $\mathrm{c}$ ). No animals died in the groups with anti-TNF- $\alpha$ or 2 -APB treatment, and there was a significant improvement in animal survival in comparison with those treated with GalN/LPS $(P<0.05)$.

\section{Anti-TNF- $\alpha$ Antibodies and 2-APB Increased GFR of Animals with FHF}

FITC-inulin clearance was measured under a steady-state condition. After implantation of micro-osmotic pumps in the peritoneal cavity, the animals experienced significant a weight loss over a few days and then gradually recovered to a preoperative weight by day 7 . Therefore, inulin clearance was determined 7 days after the implantation. GFR was calculated from plasma inulin levels and a known pump infusion rate. GalN/LPS intoxication decreased GFR1 to $33 \%$ of N.S. controls. GFR 1 values in anti-TNF- $\alpha$-GalN/LPS group and 2-APB-GalN/LPS group were significantly improved compared with that in GalN/LPS group (Figure 3a). Moreover, GFR values were presented in Figure $3 \mathrm{a}$ after a correction of body weight (per kilogram, $\mathrm{GFR}_{2}$ ) and kidney weight (per gram, $\mathrm{GFR}_{3}$ ), and the latter verified the decrease in renal function during FHF caused by GalN/LPS intoxication and the prevention by either anti-TNF- $\alpha$ or $\alpha$-APB administration.

\section{Effects of Anti-TNF- $\alpha$ Antibodies and 2-APB on Expression of $I P_{3} R 1$ Protein}

Western blot analysis was carried out to determine $\mathrm{IP}_{3} \mathrm{R} 1$ protein levels. Renal $\mathrm{IP}_{3} \mathrm{R} 1$ protein was increased in GalN/ LPS-treated group and the maximal level was seen at $12 \mathrm{~h}$ (Figure $3 \mathrm{~b}$ ) when compared with NS controls, whereas IP ${ }_{3} \mathrm{R} 1$ in GalN group or LPS group was not different from N.S. control group, which indicated that a single GalN or LPS exposure did not significantly affect $\mathrm{IP}_{3} \mathrm{R} 1$ protein levels (Figure 3c). Injection of anti-TNF- $\alpha$ antibodies dramatically reversed $\mathrm{IP}_{3} \mathrm{R} 1$ protein levels in GalN/LPS-exposed animals, whereas 2-APB did not significantly affect $\mathrm{IP}_{3} \mathrm{R} 1$ levels in GalN/LPS-exposed animals (Figure 3d). In summary,
anti-TNF- $\alpha$ antibodies, but not $2-\mathrm{APB}$, significantly retained renal $\mathrm{IP}_{3} \mathrm{R} 1$ protein levels in animals with $\mathrm{FHF}$.

\section{Effects of Anti-TNF- $\alpha$ Antibodies and 2-APB on Renal IP $_{3}$ R1 mRNA Levels}

To determine whether the increased $\mathrm{IP}_{3} \mathrm{R} 1$ protein level in GalN/LPS-exposed rats was caused by enhanced gene expression, renal $\mathrm{IP}_{3} \mathrm{R} 1 \mathrm{mRNA}$ levels were evaluated by quantitative RT-PCR. As shown in Figure $4 a, \mathrm{IP}_{3} \mathrm{R} 1 \mathrm{mRNA}$ levels were gradually increased along with the duration after GalN/LPS exposure. It increased to nearly threefold as early as $3 \mathrm{~h}$ compared with the controls, peaked at $9 \mathrm{~h}$, and reached $\sim 10$-fold. In animals with injection of anti-TNF- $\alpha$ antibodies, $\mathrm{IP}_{3} \mathrm{R} 1 \mathrm{mRNA}$ levels were strikingly reduced compared with those with GalN/LPS exposure. In contrast, 2-APB did not significantly alter the enhanced $\mathrm{IP}_{3} \mathrm{R} 1$ gene expression (Figure $4 \mathrm{~b}$ ). Therefore, the mRNA data are consistent with protein levels, and upregulated $\mathrm{IP}_{3} \mathrm{R} 1$ mRNA expression in GalN/LPS-exposed rats was abrogated by anti-TNF- $\alpha$ antibodies, but not by 2 -APB.

\section{Effects of Anti-TNF- $\alpha$ Antibodies and 2-APB on GIS}

The changes in GIS reflect the glomerular size, and indirectly indicate the vascular dilation/constriction status. The ratio of GIS2 (treated by ET-1) over GIS1 (control) is shown in Figure 4c. GalN/LPS exposure markedly decreased GIS ratio compared with N.S. controls. GIS ratio in GalN/LPS + anti-TNF- $\alpha$ group and GalN/LPS + 2-APB group was improved compared with that in the GalN/LPS group. Administration of either GalN or LPS alone caused a mild decrease in GIS ratio compared with the N.S. group.

\section{Effects of Anti-TNF- $\alpha$ Antibodies and 2-APB on Glomerular $\left[\mathrm{Ca}^{2+}\right] \mathbf{i}$}

The basal $\left[\mathrm{Ca}^{2+}\right] \mathrm{i}$ was calculated according to the equation, and sustained $\left[\mathrm{Ca}^{2+}\right] \mathrm{i}$ was calculated as the average value of $0.1 \mathrm{~s}$ exposure at $20.0 \mathrm{~s}$ intervals during ET-1 exposure for 10 min. Since cell numbers of each glomerulus could be different, which might affect the value of $\left[\mathrm{Ca}^{2+}\right]$ i, we used the ratio of sustained over basal $\left[\mathrm{Ca}^{2+}\right] \mathrm{i}$ to represent the effects of anti-TNF- $\alpha$ and 2-APB (Figure 4d). GalN/LPS exposure increased $\left[\mathrm{Ca}^{2+}\right] \mathrm{i}$ robustly compared with N.S. controls. The pre-administration of anti-TNF- $\alpha$ reduced the $\left[\mathrm{Ca}^{2+}\right]$ i level markedly, so did the pre-administration of 2-APB.

\footnotetext{
Figure 2 Renal electronic microscopic images in GalN/LPS-induced acute liver failure. Renal ultrastructure of GalN/LPS-induced acute liver failure was examined under electron microscope. (a) NS controls: glomerulus $\left(A_{1}\right)$, proximal tubule $\left(A_{2}\right)$ and distal tubule $\left(A_{3}\right)$. (b) Renal ultrastructure of rats $12 \mathrm{~h}$ after GalN/LPS exposure. Glomerulus $(G)\left(B_{1}\right)$, proximal tubule (PT) $\left(B_{2}\right)$ and distal tubule (DT) $\left(B_{3}\right)$. (c) Renal ultrastructure in GalN control rats. Glomerulus $\left(C_{1}\right)$, proximal tubule $\left(C_{2}\right)$ and distal tubule $\left(C_{3}\right)$. (d) Renal ultrastructure in LPS control rats. Glomerulus $\left(D_{1}\right)$, proximal tubule $\left(D_{2}\right)$ and distal tubule $\left(D_{3}\right)$. No significant abnormalities were found in the glomerulus, proximal and distal tubule of rats with GaIN/LPS exposure, nor were in rats treated with GalN or LPS alone.
} 
a

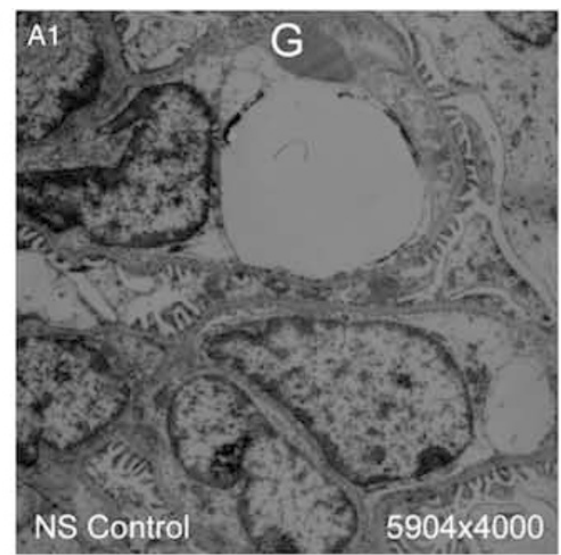

b

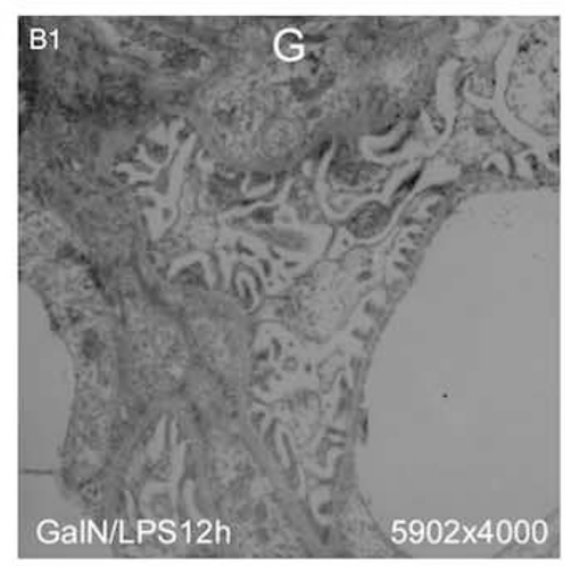

c

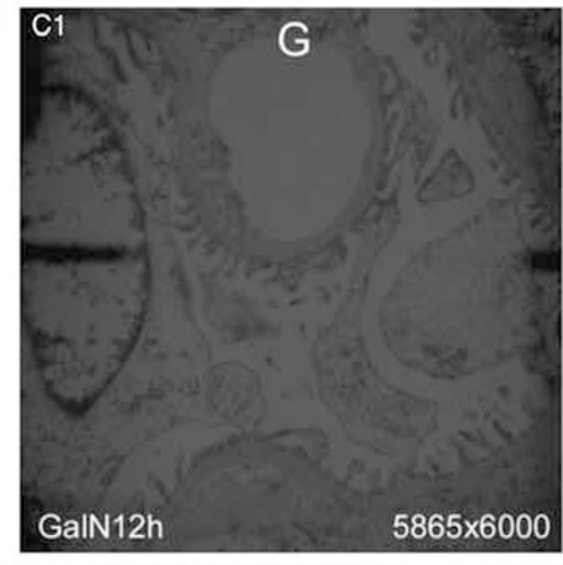

d

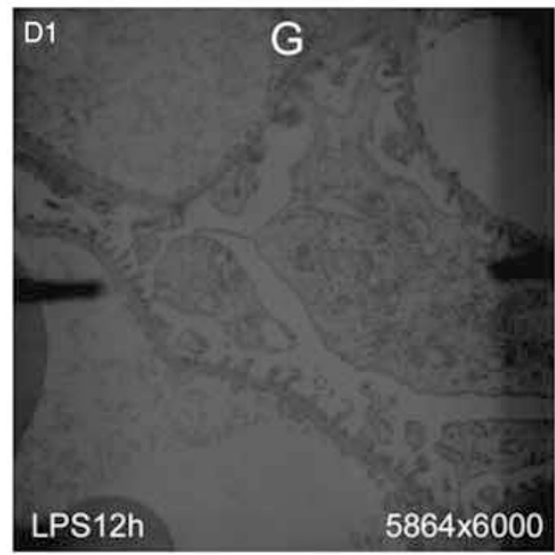

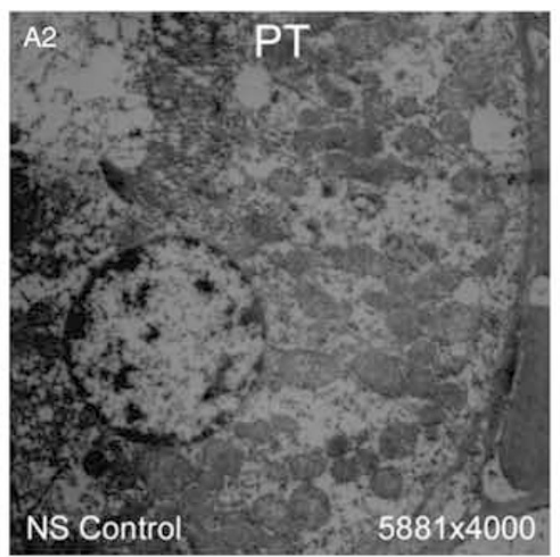
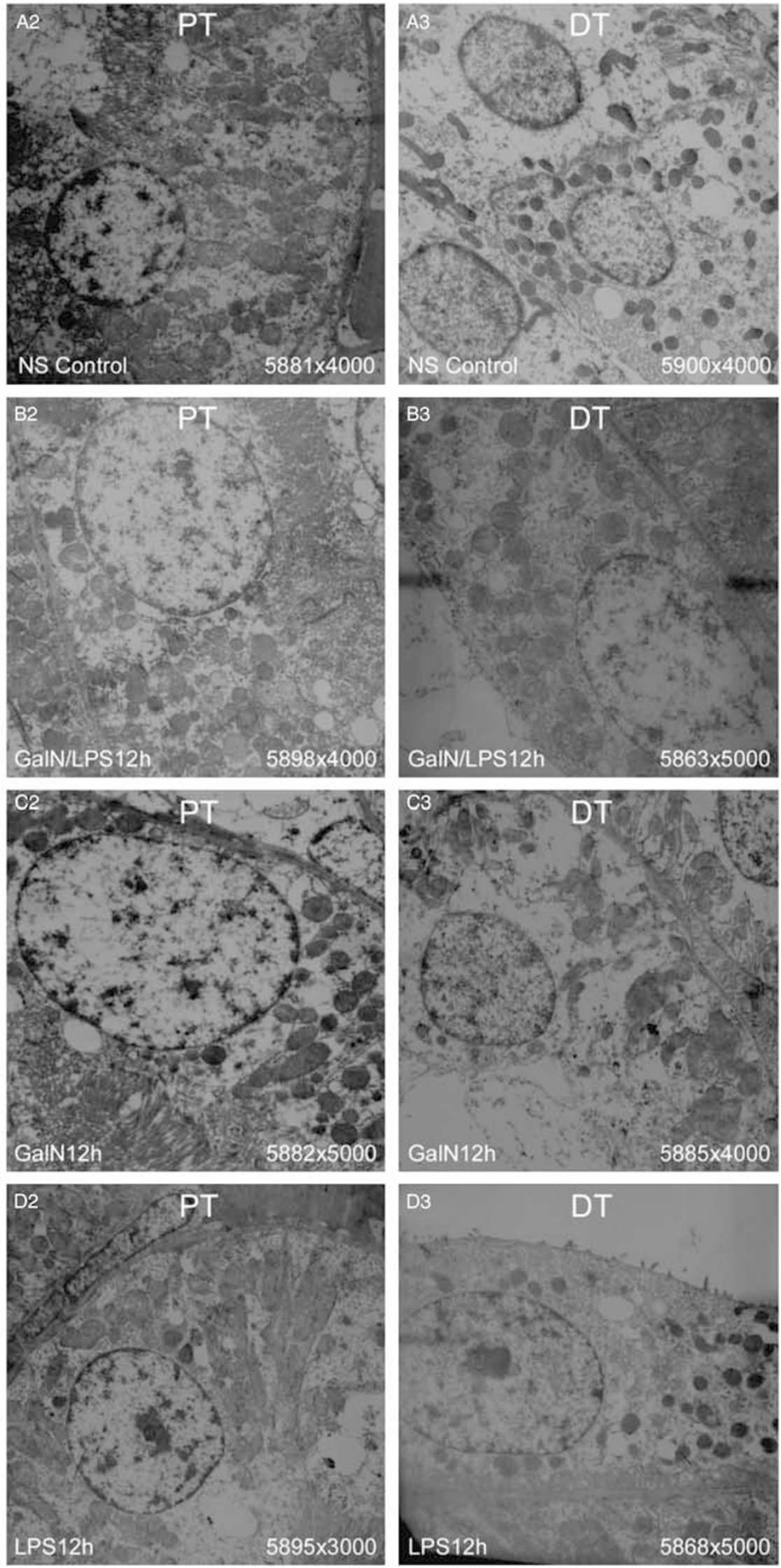
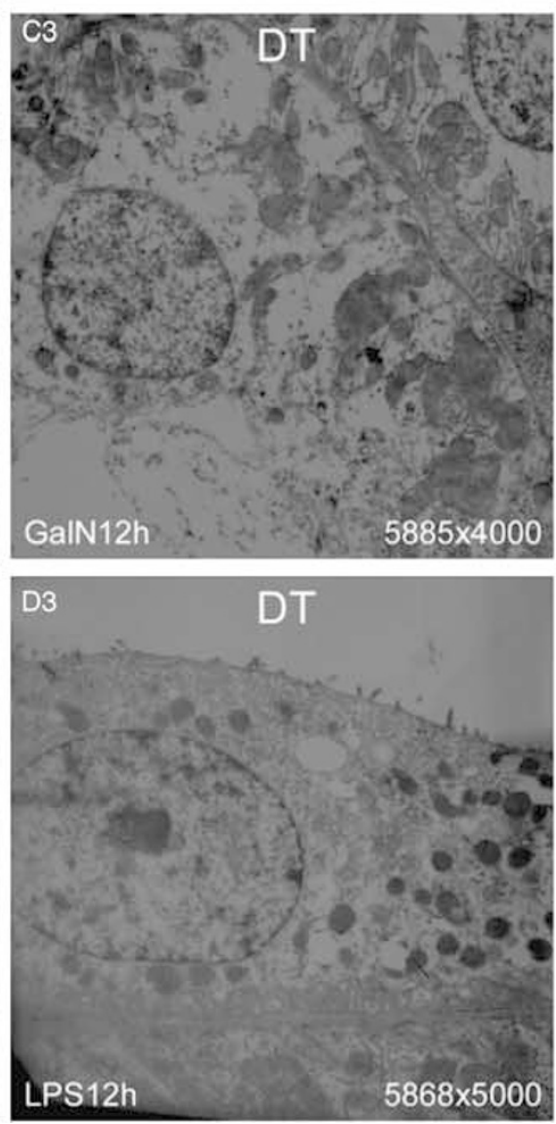

Figure 2 For caption see page 745. 
a

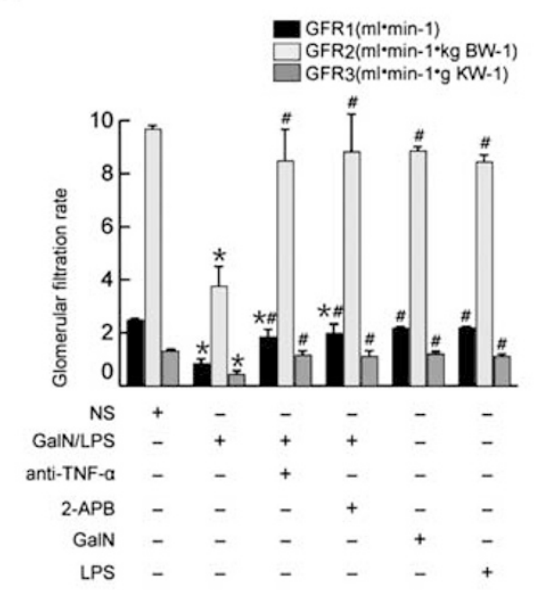

C
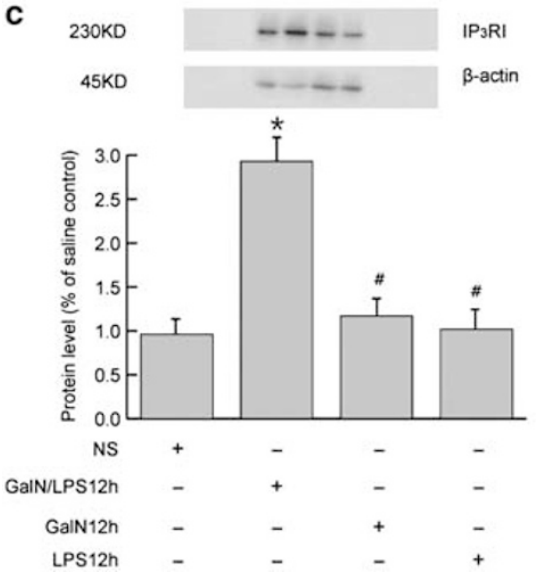

b

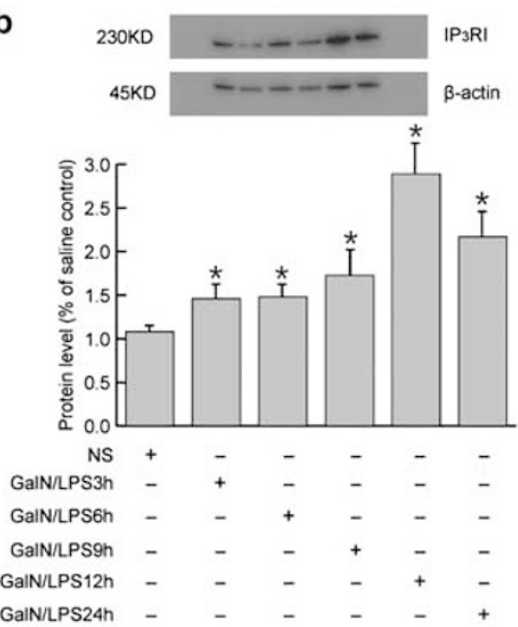

d

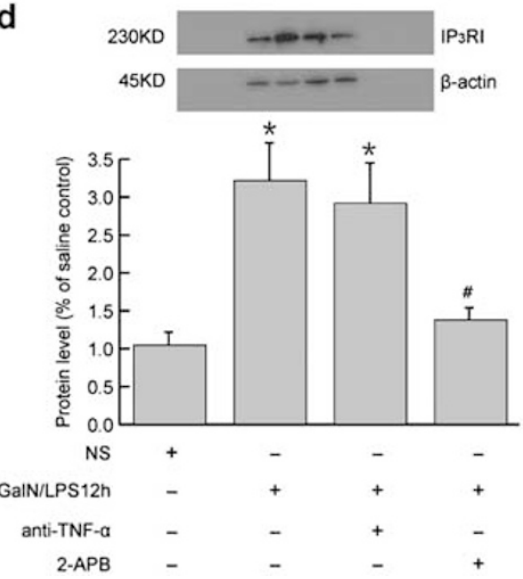

Figure 3 Effects of anti-TNF- $\alpha$ antibody on GFR and IP ${ }_{3}$ RI protein levels. GFR1 was determined by the measurement of FITC-inulin clearance under steady-state (equilibrium) conditions after implantation of micro-osmotic pumps and further corrected by body weight (BW) (GFR2) and kidney weight (KW) (GFR3) (a). Western blot analysis of $I_{3} R 1$ protein level change after GalN/LPS treatment (b). Effect of GalN or LPS alone on IP ${ }_{3} R 1$ protein levels significantly (c). Effect of $\mathrm{IP}_{3} \mathrm{R} 1$ protein expression of anti-TNF- $\alpha$ antibodies or 2-APB (d). Data represent means \pm s.e.m. $(n=3)$. ${ }^{*} P<0.05$ compared with saline controls. ${ }^{\#} P<0.05$ compared witho GalN/LPS group.

\section{Effects of Anti-TNF- $\alpha$ Antibodies and 2-APB on Serum Parameters}

A striking increase in ALT induced by GalN/LPS was decreased more significantly by the administration of anti-TNF- $\alpha$ antibodies than 2-APB (Figure 5A1). The pre-administration of anti-TNF- $\alpha$ antibodies reduced the serum levels of BUN, $\mathrm{Cr}, \mathrm{K}^{+}$and $\mathrm{Cl}^{-}$in GalN/LPS-exposed animals, so did the pre-administration of 2-APB, but restored serum $\mathrm{Na}^{+}$levels (Figure 5A2, B1, B2, A3, B3). The serum level of TNF- $\alpha$ was dramatically reduced by pre-administration of anti-TNF- $\alpha$ antibodies compared with that in the GalN/LPS group, whereas pre-administration of 2-APB did not significantly change serum TNF- $\alpha$ levels (Figure 5A4). Neither pre-administration of anti-TNF- $\alpha$ antibodies nor pre-administration of 2-APB significantly affected serum levels of ET-1 (Figure 5B4).

\section{DISCUSSION}

There is no valuable animal model available representing marked renal dysfunction without structural or histologic alteration in severe hepatic damage. In the present study, we found that $70 \%$ of rats died $24 \mathrm{~h}$ after GalN/LPS challenge. Serum ALT levels were increased 92-fold compared with controls and massive liver necrosis was evident $12 \mathrm{~h}$ after GalN/LPS exposure. Thus, this GalN/LPS regimen caused FHF in rats as we previously reported. ${ }^{14}$ At the same time, we observed that BUN and $\mathrm{Cr}$ started to increase $\sim 3 \mathrm{~h}$ after GalN/LPS exposure and peaked at $12 \mathrm{~h}$, and LPS alone caused a mild increase in serum creatinine and ET-1 levels, whereas serum sodium levels were decreased in rats with GalN/LPS challenge. Moreover, ET-1 level was increased $\sim 1.6$-fold at $6 \mathrm{~h}$ and peaked (5.2-fold) $12 \mathrm{~h}$ after GalN/LPS treatment. GFR was reduced to $33 \%$ of the controls $12 \mathrm{~h}$ after GalN/LPS 
a
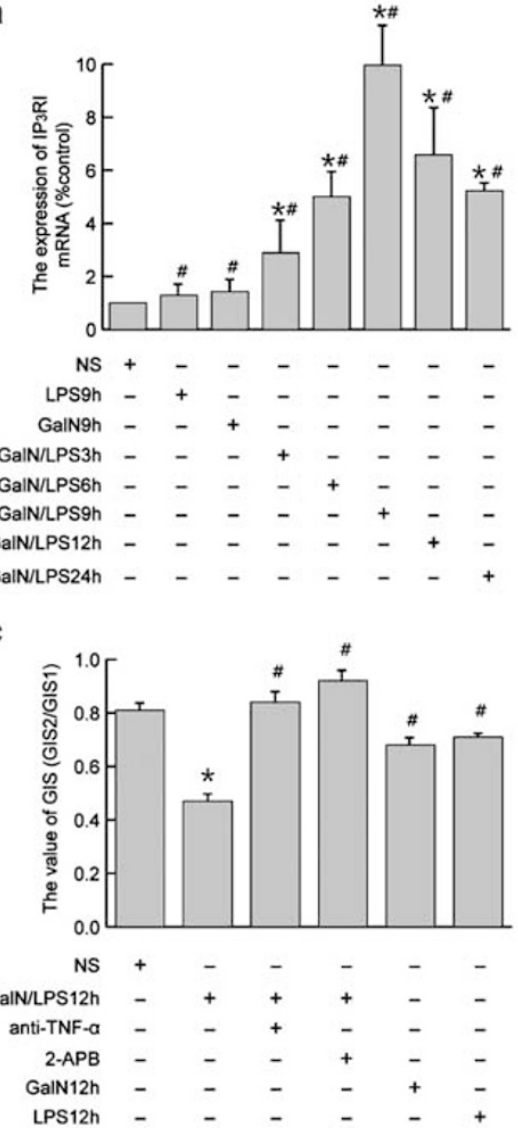

b

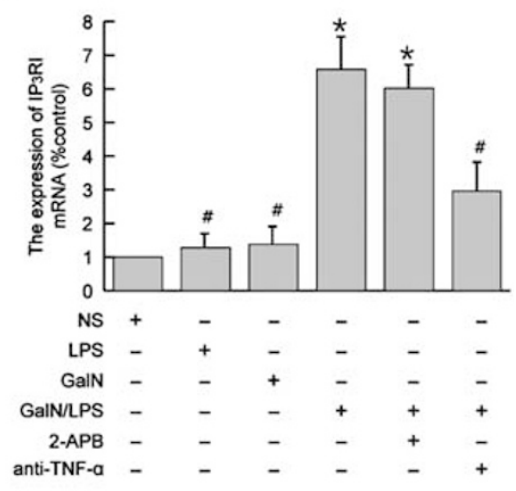

d

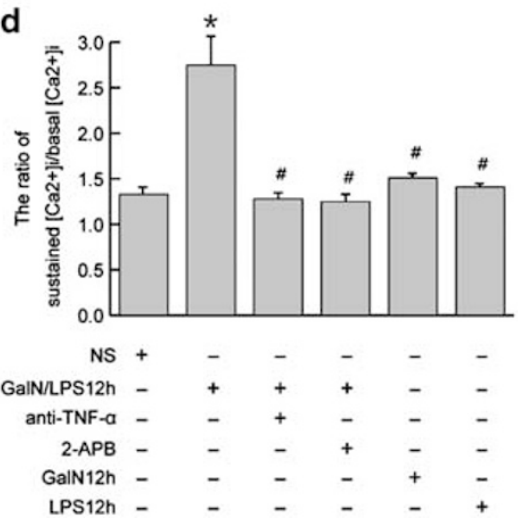

Figure 4 Effect of anti-TNF- $\alpha$ antibody on $\mathrm{P}_{3} \mathrm{RI}$ mRNA levels, glomerular inulin space (GIS) and glomerular calcium content. Rats were treated with GalN/LPS treatment. RNA was extracted from renal tissues at the indicated time points. $(a) I P_{3} R 1$ mRNA levels change after GalN/LPS exposure. (b) Effect of anti-TNF- $\alpha$ antibodies or 2-APB on $\mathrm{PP}_{3} \mathrm{R} 1$ mRNA levels. (c) GIS ratio was determined in isolated glomeruli in the presence of FITC-inulin. GIS2 represents the condition with the treatment of ET-1, whereas GIS1 was used a control. (d) The ratio of basal over sustained [Ca ${ }^{2+}$ ]i was used to present calcium-level changes after GaIN/LPS exposure and the treatment with anti-TNF- $\alpha$ or 2-APB. Data are represented as means \pm s.e.m. ( $n=4$ or 5$) .{ }^{*} P<0.05$ as compared with N.S. control group. ${ }^{\#} P<0.05$ compared with GalN/LPS group.

exposure. We did not see any significant change in renal histopathology in the rats with FHF by both routine $\mathrm{H}-\mathrm{E}$ staining and EM examination. All these changes are in accordance with previous reports regarding the hemodynamics and renal function in rats with hepatic failure. ${ }^{27-30}$ Taking together, these data confirmed that we successfully established an animal model of functional renal failure in rats with FHF. To exclude effects of the systemic circulation on renal function, we simultaneously monitored SBP of animal models in order to exclude the prerenal azotemia. Moreover, our model is superior to other models caused by hepatic ischemia/reperfusion-induced acute injury or carbon tetrachloride $\left(\mathrm{CCl}_{4}\right)$-induced cirrhosis because either these two models displayed striking renal morphologic changes, such as acute tubular necrosis, inflammatory changes and interstitial capillary endothelial apoptosis. ${ }^{31,32}$

Several hypotheses have been proposed to explain the development of acute renal failure in FHF. The common one is that splanchnic and peripheral vasodilation with reduction in effective arterial volume causes intense renal vasocon- striction and functional renal failure. ${ }^{33}$ In short, renal perfusion is maintained within normal or nearly normal limits as the vasodilatory system antagonizes the renal effects of the vasoconstrictor systems in the early phase of portal hypertension. However, as liver disease progresses in severity, the renal vasodilatory system is unable to counteract the maximal activity of the endogenous vasoconstrictors and/or intrarenal vasoconstrictors, and the consequence is an uncontrolled renal vasoconstriction. Therefore, it is conceivable that the intense vasoconstriction of the renal circulation is the major pathophysiologic mechanism leading to renal failure in FHF. TNF- $\alpha$ is a pleiotropic proinflammatory cytokine that is involved in many biological and pathological processes. In GalN/LPS-induced FHF, LPS might stimulate macrophages and monocytes to release TNF- $\alpha .{ }^{34,35}$ We have found a widespread destruction of liver architecture as well as infiltration of inflammatory cells in liver sections of rats after injection of GalN plus LPS. The pathologic changes in the liver were worst $12 \mathrm{~h}$ after the GalN/LPS exposure; however, there are no striking 
a $\mathrm{A}$

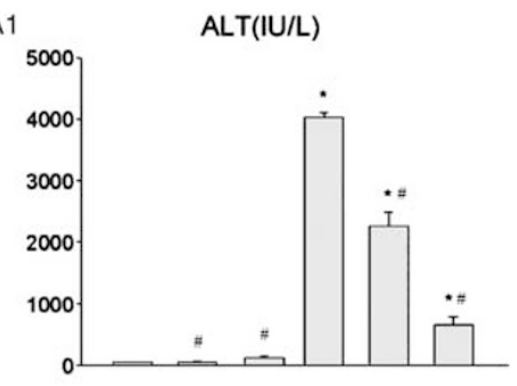

A2

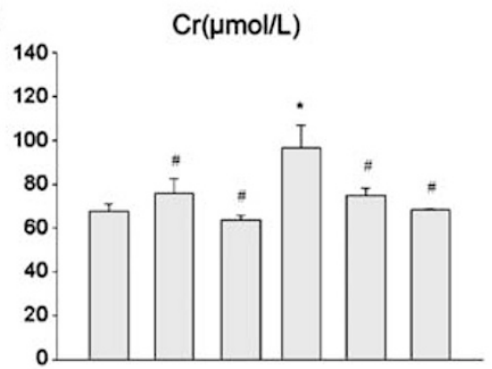

A3

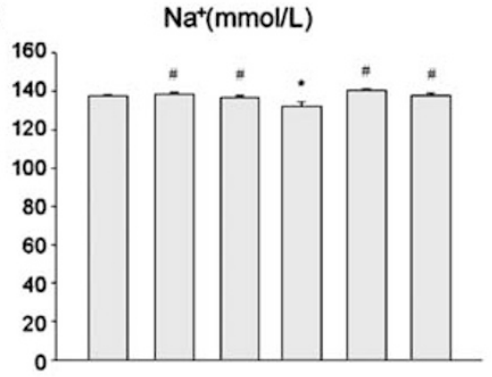

A4

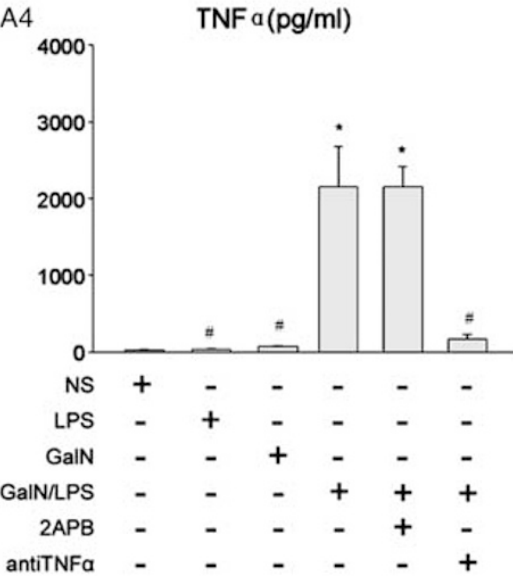

B1

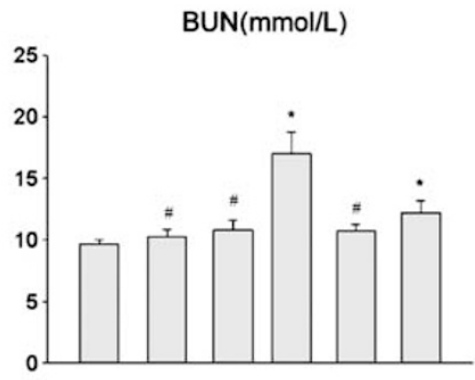

B2

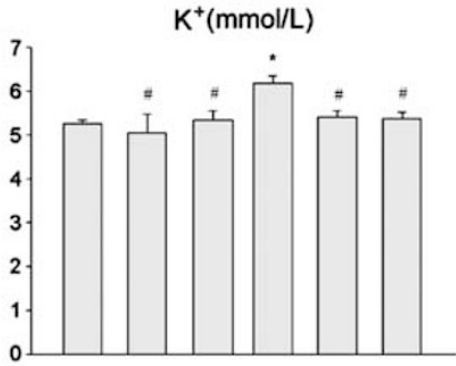

B3

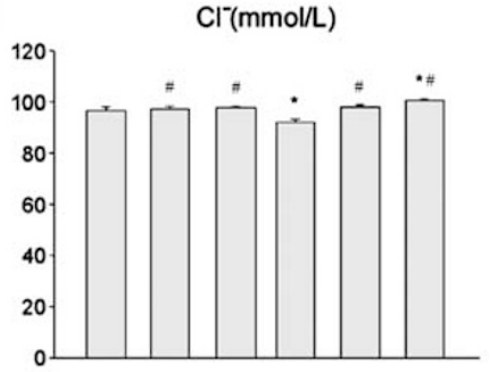

B4

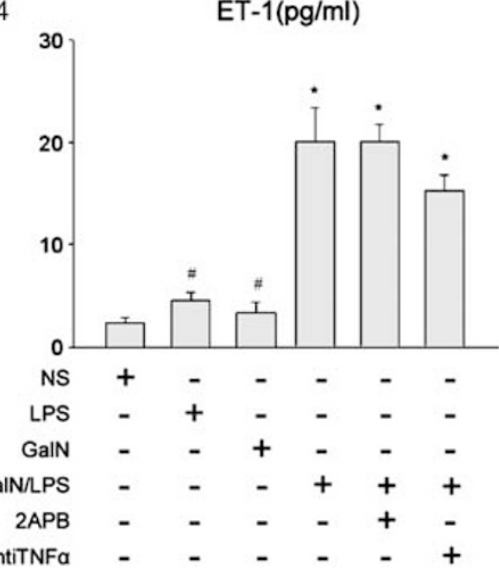

Figure 5 Effect of anti-TNF- $\alpha$ antibody and 2-APB on serum levels of biochemical markers and cytokines. See experimental details in the Materials and Methods section. (A1) ALT, (B1) BUN, (A2) $\mathrm{Cr}$, (B2) $\mathrm{K}^{+}$, (A3) $\mathrm{Na}^{+}$, (B3) $\mathrm{Cl}^{-}$, (A4) TNF- $\alpha$, (B4) ET-1. Data are presented as means \pm s.e.m. ( $n=4$ or 5). ${ }^{*} P<0.05$ compared with N.S. group. ${ }^{\#} P<0.05$ compared with GalN/LPS group.

morphologic changes, but only a slight increase in serum creatinine and ET-1 levels in LPS-treated animals. Simultaneously serum TNF- $\alpha$ level reached a maximum level, in an occurrence with the lowest GFR in rats with FHF. When TNF- $\alpha$ was blocked by a monoclonal TNF- $\alpha$ antibody, the mortality rate of GalN/LPS-treated rats was significantly decreased from $70 \%$ to zero, and the compromised GFR was also improved significantly. Therefore, TNF- $\alpha$ had an indispensable role in the development of renal failure during FHF, and might be one of crucial factors causing declination in GFR directly or indirectly. However, it is unclear whether TNF- $\alpha$ leads to acute renal failure secondary to hepatic failure, or directly acts on the kidneys, because we can't completely rule out the direct effects of LPS on renal 
function. However, the dose of LPS we used was much lower than reported. ${ }^{36}$

$\mathrm{IP}_{3} \mathrm{Rs}$ are the intracellular $\mathrm{Ca}^{2+}$ release channels that have a key role in $\mathrm{Ca}^{2+}$ signaling in cells. ${ }^{37}$ Growing evidence indicates that $\mathrm{TNF}-\alpha$ upregulated $\mathrm{IP}_{3} \mathrm{R} 1$ expression, and that the upregulation correlates with alterations in $\mathrm{Ca}^{2+}$ homeostasis in many conditions. ${ }^{38,39}$ We demonstrated in a recent study that TNF- $\alpha$ enhanced $\mathrm{IP}_{3} \mathrm{R} 1$ expression at mRNA and protein levels in HMCs, and identified TNFR1/ PC-PLC/PKC $\alpha$-dependent and TNFR2-dependent IP ${ }_{3} \mathrm{R} 1$ genes. ${ }^{13}$ In the present study, the results of GIS and glomerular $\left[\mathrm{Ca}^{2+}\right] \mathrm{i}$ are in accordance with the changes of the GRF and serum parameters during the GalN/LPS exposure. High renal $\mathrm{IP}_{3} \mathrm{R} 1$ expression at both protein and mRNA levels was seen in GalN/LPS-treated rats, and was in accordance with serum ET- 1 and TNF- $\alpha$ levels. Endothelin is a potent vasoconstrictor of the renal vascular bed, and promotes $\mathrm{IP}_{3}$-mediated $\mathrm{Ca}^{2+}$ mobilization via the $\mathrm{IP}_{3} \mathrm{Rs}$, followed by release of stored intracellular $\mathrm{Ca}^{2+}$ and $\mathrm{Ca}^{2+}$ entry through plasma membrane channels. ${ }^{40}$ The increase in glomerular $\left[\mathrm{Ca}^{2+}\right] \mathrm{i}$ after GalN/LPS exposure indicates that $\mathrm{IP}_{3}$ signaling did have an important role in the mediation of calcium influx in affected kidneys, probably in GMC or renal VSMCs. The constriction of these cells significantly deceased renal blood flow rate and GIS as seen in our study. Therefore, these findings support the notion that signaling molecules, such as endothilin-1 and $\mathrm{IP}_{3} \mathrm{R} 1$ may contribute to the contraction of GMC and VSMC, which results in reduced glomerular blood flow rate, and in turn decreases GFR during the development of acute renal failure.

In GalN/LPS-treated rats, when TNF- $\alpha$ was blocked with TNF- $\alpha$ antibody, it was observed that not only was liver failure alleviated significantly but also GFR was improved strikingly. At the same time, renal $\mathrm{IP}_{3} \mathrm{R} 1$ overexpression was retained to a normal level. These findings imply a crucial role of TNF- $\alpha$ in modulating $\mathrm{IP}_{3} \mathrm{R} 1$ signaling activities and affecting GFR during FHF. In order to further prove that TNF- $\alpha$ is involved in acute renal failure by enhancing $\mathrm{IP}_{3} \mathrm{Rs}$ expression, we employed an inhibitor of $\mathrm{IP}_{3} \mathrm{Rs}(2-\mathrm{APB})$, and found that reduction in GFR was reversed by administration of 2-APB and renal function recovered, whereas 2-APB did not affect the liver injury and serum TNF- $\alpha$ and ET-1 levels. We speculate that 2-APB acted on the renal vessel bed by inhibiting the $\mathrm{IP}_{3} \mathrm{Rs}$ signaling pathway, and in turn increased GFR in rats with FHF while it has less effect on hepatic failure. These findings strongly suggested that $\mathrm{IP}_{3} \mathrm{R} 1$ overexpression in GMC and VSMC is an important molecular mechanism underlying TNF- $\alpha$-induced GFR reduction. There exists a disturbed balance of vaso-constrictive and dilative substance during fulminant liver failure, and it is not plausible that inhibition of only one vaso-constrictive substance could efficiently block an increase in $\mathrm{IP}_{3}$ and calcium levels within the GMC and VSMC. Therefore, the inhibition needs to target multiple layers at terminal steps of the signaling pathways of $\mathrm{IP}_{3} \mathrm{R} 1$ and calcium in order to achieve the blocking contractile effect of vasoconstrictor substances on GMC and VSMC. ${ }^{41}$

In conclusion, the findings in the present study demonstrate that TNF- $\alpha$-induced reduction in GFR is responsible for the development of acute renal failure during FHF. The enhanced constrictive activity of renal vascular bed caused by vasoconstrictors due to overexpression of TNF- $\alpha$-dependent $\mathrm{IP}_{3} \mathrm{R} 1$ gene and an increase in glomerular calcium levels appears to contribute to GFR reduction. The TNF- $\alpha$-dependent $\mathrm{IP}_{3} \mathrm{R} 1$ upregulation may well be an important target in the treatment of acute renal failure.

Supplementary Information accompanies the paper on the Laboratory Investigation website (http://www.laboratoryinvestigation.org)

\section{ACKNOWLEDGMENTS}

We gratefully acknowledge Drs Dong-Juan Liu and Chun-Yan Li (China Medical University, China) for technical assistance in electronic microscope and fluorescence examination. We are grateful to Dr Lu-Ping Li (The Sixth People's Hospital of Shenyang, China) for serum biochemical analysis and the comments to this manuscript. This work is supported by the Natural Science Foundation of China (No. 30270607).

\section{DISCLOSURE/CONFLICT OF INTEREST}

The authors declare no conflict of interest.

1. Moore JK, Love E, Craig DG, et al. Acute kidney injury in acute liver failure: a review. Expert Rev Gastroenterol Hepatol 2013;7:701-712.

2. Arroyo V, Fernandez J, Gines P. Pathogenesis and treatment of hepatorenal syndrome. Semin Liver Dis 2008;28:81-95.

3. Gines $P$, Guevara M, Arroyo V, et al. Hepatorenal syndrome. Lancet 2003;362:1819-1827.

4. Andresen BT, Jackson EK, Romero GG. Angiotensin II signaling to phospholipase D in renal microvascular smooth muscle cells in SHR. Hypertension 2001;37:635-639.

5. Schroeder AC, Imig JD, LeBlanc EA, et al. Endothelin-mediated calcium signaling in preglomerular smooth muscle cells. Hypertension 2000;35:280-286.

6. Fellner SK, Arendshorst WJ. Angiotensin $\mathrm{II} \mathrm{Ca}^{2+}$ signaling in rat afferent arterioles: stimulation of cyclic ADP ribose and IP3 pathways. Am J Physiol Renal Physiol 2005;288:F785-F791.

7. Shankar A, Loizidou M, Burnstock G, et al. Noradrenaline improves the tumour to normal blood flow ratio and drug delivery in a model of liver metastases. Br J Surg 1999;86:453-457.

8. Bacq Y, Gaudin C, Hadengue A, et al. Systemic, splanchnic and renal hemodynamic effects of a dopaminergic dose of dopamine in patients with cirrhosis. Hepatology 1991;14:483-487.

9. Bennett WM, Keeffe E, Melnyk C, et al. Response to dopamine hydrochloride in the hepatorenal syndrome. Arch Intern Med 1975;135:964-971.

10. Wang JY, Wang XL, Liu P. Detection of serum TNF-alpha,IFN-beta,IL-6 and IL-8 in patients with hepatitis B. World J Gastroenterol 1999;5: 38-40.

11. Takakura M, Tokushige $\mathrm{K}$, Matsushita N, et al. Possible involvement of cytokine gene polymorphisms in fulminant hepatitis. J Gastroenterol Hepatol 2007;22:1271-1277.

12. Akriviadis $E$, Botla $R$, Briggs $W$, et al. Pentoxifylline improves short-term survival in severe acute alcoholic hepatitis: a double-blind, placebocontrolled trial. Gastroenterology 2000;119:1637-1648.

13. Wang YR, Li ZG, Fu JL, et al. TNFalpha-induced IP3R1 expression through TNFR1/PC-PLC/PKCalpha and TNFR2 signalling pathways in human mesangial cell. Nephrol Dial Transplant 2011;26:75-83.

14. Wu J, Liu L, Yen RD, et al. Liposome-mediated extracellular superoxide dismutase gene delivery protects against acute liver injury in mice. Hepatology 2004;40:195-204. 
15. Hijikawa $T$, Kaibori $M$, Uchida $Y$, et al. Insulin-like growth factor 1 prevents liver injury through the inhibition of TNF-alpha and iNOS induction in D-galactosamine and LPS-treated rats. Shock 2008;29: 740-747.

16. Hem A, Smith AJ, Solberg P. Saphenous vein puncture for blood sampling of the mouse, rat, hamster, gerbil, guinea pig, ferret and mink. Lab Anim 1998;32:364-368.

17. Qi Z, Whitt I, Mehta A, et al. Serial determination of glomerular filtration rate in conscious mice using FITC-inulin clearance. Am Physiol Renal Physiol 2004;286:F590-F596.

18. Lozano JM, Padillo J, Montero JL, et al. Immunomodulatory activity of TNF-alpha during acute liver injury induced by D-galactosamine and its protection by PGE1 in rats. Int Immunopharmacol 2003;3:197-207.

19. Muntane J, Rodriguez FJ, Segado O, et al. TNF-alpha dependent production of inducible nitric oxide is involved in PGE(1) protection against acute liver injury. Gut 2000;47:553-562.

20. Nicoud IB, Knox $C D$, Jones $C M$, et al. 2-APB protects against liver ischemia-reperfusion injury by reducing cellular and mitochondrial calcium uptake. Am J Physiol Gastrointest Liver Physiol 2007;293: G623-G630.

21. Lorenz JN, Gruenstein E. A simple, nonradioactive method for evaluating single-nephron filtration rate using FITC-inulin. Am J Physiol 1999;276:F172-F177.

22. Sturgeon C, Sam 2nd AD, Law WR. Rapid determination of glomerular filtration rate by single-bolus inulin: a comparison of estimation analyses. J Appl Physiol 1998;84:2154-2162.

23. van Bemmelen MX, Szczepanska-Konkel M, Jastorff B, et al. Effect of CAMP analogues on glomerular inulin space of isolated rats renal glomeruli. J Physiol Pharmacol 2005;56:111-120.

24. Szczepanska-Konkel M, Jankowski M, Stiepanow-Trzeciak A, et al. Effects of diadenosine polyphosphates on glomerular volume. $\mathrm{Br}$ J Pharmacol 2005;144:1109-1117.

25. Fuller AJ, Hauschild BC, Gonzalez-Villalobos R, et al. Calcium and chloride channel activation by angiotensin II-AT1 receptors in preglomerular vascular smooth muscle cells. Am J Physiol Renal Physiol 2005;289:F760-F767.

26. Udagawa $\mathrm{T}$, Hanaoka $\mathrm{K}$, Kawamura $\mathrm{M}$, et al. Characteristics of spontaneous calcium oscillations in renal tubular epithelial cells. Clin Exp Nephrol 2012;16:389-398.

27. Natarajan SK, Basivireddy J, Ramachandran A, et al. Renal damage in experimentally-induced cirrhosis in rats: Role of oxygen free radicals. Hepatology 2006;43:1248-1256.
28. Li Y, Song $D$, Zhang $Y$, et al. Effect of neonatal capsaicin treatment on haemodynamics and renal function in cirrhotic rats. Gut 2003;52: 293-299.

29. Tahseldar-Roumieh R, Ghali-Ghoul R, Lugnier C, et al. Effect of phosphodiesterase 5 inhibitor on alteration in vascular smooth muscle sensitivity and renal function in rats with liver cirrhosis. Am J Physio Heart Circ Physiol 2006;290:H481-H488.

30. Fernandez-Llama P, Ageloff S, Fernandez-Varo G, et al. Sodium retention in cirrhotic rats is associated with increased renal abundance of sodium transporter proteins. Kidney Int 2005;67:622-630.

31. Jaramillo-Juarez F, Rodriguez-Vazquez ML, Rincon-Sanchez AR, et al. Acute renal failure induced by carbon tetrachloride in rats with hepatic cirrhosis. Ann Hepatol 2008;7:331-338.

32. Lee HT, Park SW, Kim M, et al. Acute kidney injury after hepatic ischemia and reperfusion injury in mice. Lab Invest 2009;89: 196-208.

33. Venkat D, Venkat KK. Hepatorenal syndrome. South Med J 2010;103:654-661.

34. Bang R, Sass G, Kiemer AK, et al. Neurokinin-1 receptor antagonists CP96345 and L-733060 protect mice from cytokine-mediated liver injury. J Pharmacol Exp Ther 2003;305:31-39.

35. Nguyen $\mathrm{JH}$, Yamamoto $\mathrm{S}$, Steers $\mathrm{J}$, et al. Matrix metalloproteinase- 9 contributes to brain extravasation and edema in fulminant hepatic failure mice. J Hepatol 2006;44:1105-1114.

36. Zhao ZG, Niu CY, Zhang LL, et al. Exogenous normal lymph alleviates lipopolysaccharide-induced acute kidney injury in rats. Ren Fail 2013:35:806-811.

37. White C, McGeown JG. Inositol 1,4,5-trisphosphate receptors modulate $\mathrm{Ca}^{2+}$ sparks and $\mathrm{Ca}^{2+}$ store content in vas deferens myocytes. Am J Physiol Cell Physiol 2003;285:C195-C204.

38. Park KM, Yule DI, Bowers WJ. Tumor necrosis factor-alpha potentiates intraneuronal $\mathrm{Ca}^{2+}$ signaling via regulation of the inositol 1,4,5trisphosphate receptor. J Biol Chem 2008;283:33069-33079.

39. Xu C, Bailly-Maitre B, Reed JC. Endoplasmic reticulum stress: cell life and death decisions. J Clin Invest 2005;115:2656-2664.

40. Zhu Z, Arendshorst WJ. Angiotensin II-receptor stimulation of cytosolic calcium concentration in cultured renal resistance arterioles. Am J Physiol 1996;271:F1239-F1247.

41. Ding $Y$, Stidham RD, Bumeister $R$, et al. The synthetic triterpenoid, RTA 405 , increases the glomerular filtration rate and reduces angiotensin II-induced contraction of glomerular mesangial cells. Kidney Int 2013:83:845-854. 